\title{
Biodegradable, non-bactericidal oxygen-functionalised imidazolium esters: A step towards 'greener' ionic liquids $\dagger$
}

\author{
Saibh Morrissey, ${ }^{a}$ Bruce Pegot, ${ }^{a}$ Deborah Coleman, ${ }^{a}$ M. Teresa Garcia,${ }^{b}$ Damien Ferguson, ${ }^{c}$ Bríd Quilty ${ }^{c}$ \\ and Nicholas Gathergood $* a$
}

\author{
Received 25th July 2008, Accepted 18th February 2009 \\ First published as an Advance Article on the web 18th March 2009 \\ DOI: $10.1039 / \mathrm{b812809j}$
}

A series of imidazolium ionic liquids was prepared and screened against 7 bacterial strains. The incorporation of ether groups into the ester side-chain significantly reduced the toxicity compared with alkyl ester derivatives. Biodegradation data are also presented for 15 of the ionic liquids - including 6 examples which can be classed as readily biodegradable.

\section{Introduction}

Ionic liquids (ILs) have been under study as a replacement for volatile organic compounds (VOCs) and are now used as media for a variety of organic and inorganic reactions, ranging from catalytic hydrogenation ${ }^{1,2}$ and hydroformylation ${ }^{3}$ to the Friedel-Crafts ${ }^{4}$ and Diels-Alder ${ }^{5}$ reactions. ILs have also proved useful in the physical sciences, with applications emerging in analytical separations, ${ }^{6}$ near-infrared luminescence ${ }^{7}$ and photomagnetism. ${ }^{8}$

A significant research effort ensued when ILs emerged as a possible 'green' alternative to common organic solvents. ${ }^{9}$ Although their negligible vapour pressures ${ }^{10}$ render ILs attractive alternatives to VOCs, other release routes aside from evaporation to the environment must be addressed before ILs can officially be categorised as 'green'.

In recent years investigations have commenced into the biological impact of ILs on the environment. With the field of ILs continuing to shift from the research laboratory to an industrial setting, ${ }^{11-13}$ toxicity and biodegradability have become additional factors to be considered before ILs gain acceptance as viable alternatives to VOCs.

Toxicological and ecotoxicological data for ILs have been collected using test systems based on different biological complexity levels. Toxicity and antimicrobial studies have been performed on a range of bacteria and fungi, ${ }^{14-17}$ acute toxicity studies have been carried out on fish, ${ }^{18}$ growth inhibition studies have been carried out on algae, ${ }^{19,20,21}$ and also on terrestrial plants. ${ }^{22,23}$ The variety of organisms studied now extends to higher classes such as the soil nematode ${ }^{24}$ and the freshwater snail. ${ }^{25}$

Most of the ionic liquids studied have been of the imidazolium and pyridinium classes, with alkyl or alkyloxy side-chains,

\footnotetext{
${ }^{a}$ National Institute for Cellular Biotechnology, School of Chemical Sciences, Dublin City University, Glasnevin, Dublin 9, Ireland. E-mail: Nick.Gathergood@dcu.ie; Fax:+3531700 5503;Tel: +3531 7007860

${ }^{b}$ Department of Surfactant Technology, IIQAB-CSIC, Jordi Girona, Spain

'National Institute for Cellular Biotechnology and School of Biotechnology, Dublin City University, Glasnevin, Dublin 9, Ireland $\dagger$ Electronic supplementary information (ESI) available: Further experimental procedures and biodegradation results. See DOI: $10.1039 / \mathrm{b} 812809 \mathrm{j}$
}

containing the anions, bromide $\left(\mathrm{Br}^{-}\right)$, chloride $\left(\mathrm{Cl}^{-}\right)$, hexafluorophosphate $\left(\mathrm{PF}_{6}{ }^{-}\right)$, and tetrafluoroborate $\left(\mathrm{BF}_{4}^{-}\right)$. Preliminary experiments on the effects of ILs on rat cell lines and also human Caco-2 cell lines have been conducted, ${ }^{26,27,28}$ as well as enzymatic studies. $^{29}$

Results from these investigations prove that the toxicity of ILs increases with increasing alkyl chain length. This could be explained by the increased lipophilic character of the IL with increasing alkyl chain length, which may lead to IL incorporation into biological membranes and disruption of membrane proteins (polar narcosis). ${ }^{30}$ The resulting increase in cell membrane permeability may also adversely affect the ability of cells to resist or repair membrane disruption. ${ }^{21}$

The contribution of ILs to anthropogenic waste is a major factor hindering their valid classification as 'green solvents'. To date, limited research has been carried out to determine the biodegradability of ILs. ${ }^{31-39}$

Although an extensive range of ILs have been synthesized and tested for environmental toxicity, little research has been conducted in which the design of the ILs is the chief factor in reducing their environmental impact. ${ }^{40}$

The work of Gathergood and Scammells in the field of biodegradable ILs began in $2002^{31}$ when they applied the same principles that are used in the synthesis of biodegradable surfactants to the design of ILs. A modified Sturm test (ISO9439) was used to evaluate the biodegradability of imidazolium ILs that have ester-linked side-chains. In these studies the most readily degraded IL gave a biodegradation of $59 \%$, close to the pass level for this test $(60 \%)$.

Gathergood et al..$^{32}$ proceeded to test ILs for biodegradability, using the 'Closed Bottle Test' (OECD 301D) together with a modified Sturm test (OECD 301B). The ILs that incorporated an ester linkage in the side-chain showed a significant increase in biodegradation (close to $40 \%$ ) when compared with their commercially available counterparts, $[\mathrm{bmim}]\left[\mathrm{BF}_{4}\right]$ and $[\mathrm{bmim}]\left[\mathrm{PF}_{6}\right]$ that show negligible biodegradation.

After studies by Garcia et al. ${ }^{33}$ confirmed that the presence of an ester linkage promoted biodegradation, a range of ILs both with and without ester groups, were examined. Garcia determined that in both classes of IL, the octylsulfate counter ion showed the highest biodegradation. However, none of the ILs synthesized could yet be described as readily biodegradable. 
Ultimately, by combining the features of a propyl or pentyl ester side-chain with the octylsulfate counterion, Gathergood et al. ${ }^{34}$ were able to synthesize the first 'readily biodegradable ILs'. Two complementary test methods were chosen to investigate the biodegradability of Scammells and Gathergood's ILs. Firstly, using the 'Closed Bottle Test' (OECD 301D), reference test compounds $[\mathrm{bmim}][\mathrm{Br}]$ and $[\mathrm{bmim}]\left[\mathrm{BF}_{4}\right]$ showed the lowest biodegradation level $(0-1 \%)$. Imidazolium bromide salts containing ester moieties showed improved biodegradation (23$33 \%$ ), while the octylsulfate ILs containing esters gave a further improvement in biodegradation levels (49-56\%). These results were corroborated using the $\mathrm{CO}_{2}$ Headspace test (ISO 14593). It was with ISO 14593 that the most impressive biodegradation levels so far were obtained (60-66\%), with ILs containing an ester moiety and also the octylsulfate counter anion. Monitoring the disappearance of substrates during biodegradation tests by a battery of analytical tests, including NMR and HPLC is highly desirable, but if methods that take account of respirometric parameters, such as $\mathrm{O}_{2}$ depletion $(\mathrm{OECD} 301 \mathrm{D})$ and $\mathrm{CO}_{2}$ formation (e.g. ISO9439, OECD 301B, ISO 14593) are neglected then the analysis cannot be relied upon to reflect biodegradation of a test sample. ${ }^{41}$

Herein we disclose the synthesis of a library of imidazoliumbased ILs that enables us to compare the toxicity and biodegradability of the reported butyl (1a-f) and pentyl (2a-f) imidazolium esters $^{34}$ with decyl imidazolium ester $\mathbf{1 2}^{\mathbf{4 2}}$ as well as novel esters derived from ethylene glycol, diethylene glycol and triethylene glycol, with oxygenated side-chains ranging from 4 to 10 atoms in length. (Fig. 1).

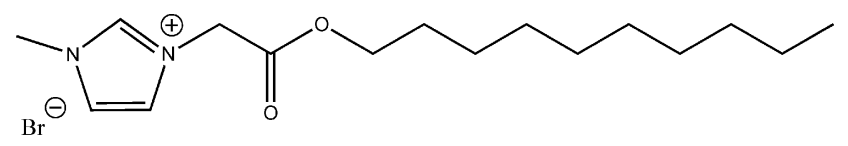<smiles>CCCCCOC(=O)Cn1cc2c(O)c1OC2</smiles><smiles>COCCOC(=O)Cn1cc2cc1C2</smiles>

Fig. 1 Oxygen functionalized ILs.

\section{Results and discussion}

\section{Synthesis}

Synthesis of the ILs described herein is carried out in two steps followed by anion exchange (Fig. 2).

The commercially available alcohols were reacted with bromoacetyl bromide to form the desired alkylating agents in good yields $(62-88 \%)$. Pure 2-bromoesters were then obtained by distillation of the crude product under high vacuum to give colourless to pale yellow oils. This reaction was performed at scales up to $500 \mathrm{mmol}$ with no compromise in yield or purity.

Subsequent alkylation of either 1-methylimidazole or 1,2dimethylimidazole by the 2-bromoester at $-15^{\circ} \mathrm{C}$ for 3 hours, then at $20^{\circ} \mathrm{C}$ for 18 hours resulted in precipitation of the desired bromide salt in good yields (82-98\%). However, only moderate yields (55\% and $51 \%$, respectively) were recorded for two of the long-chain esters, 11a and 12a.

Although four of the bromide salts were viscous liquids (1a, 2a, 13a, 15a) in most cases the bromides were solids at $20{ }^{\circ} \mathrm{C}$. However, with only five exceptions (solids, 3d, 10e, 13f, 15d and 15f) amongst the other counter-ions the remaining 66 esters were liquid at $20{ }^{\circ} \mathrm{C}$, and even considering the solid examples, in no case did the melting point of the esterfunctionalised ILs exceed $75^{\circ} \mathrm{C}$ (significantly below the $100^{\circ} \mathrm{C}$ limit for definition as ILs, Table 1).

The final counter-ion metathesis was carried out using potassium hexafluorophosphate, sodium tetrafluoroborate, sodium dicyanoamide, lithium trifluoromethanesulfonimide or sodium octylsulfate. This exchange is important as it results in changes to the bulk solvent properties of the corresponding IL. In most cases, the anion exchange reaction leads to ILs with decreased melting points, compared with their bromide salt analogues. This alteration in physical properties is especially marked in the case of the trifluoromethanesulfonimide $\left(\mathrm{NTf}_{2}^{-}\right)$salts, which were all liquids at $20{ }^{\circ} \mathrm{C}$ and appeared to be significantly less viscous than the other salts. The $\mathrm{NTf}_{2}{ }^{-}$salt was readily prepared by a simple reaction of the bromide IL with lithium trifluoromethanesulfonimide in water over 4-18 hours, which gave the desired IL as a separate phase, beneath the aqueous layer. The ion-exchange reactions proceeded in good yields (69$96 \%$ ) and simply washing the hydrophobic IL with water proved to be an effective means of removing trace impurities.

In common with the trifluoromethanesulfonimide ILs, the $\mathrm{PF}_{6}{ }^{-}$salts formed a biphasic mixture with water. In most cases the hexafluorophosphate ILs exhibit slightly increased melting points, when compared with the $\mathrm{NTf}_{2}{ }^{-}$ILs (Table 1). A different

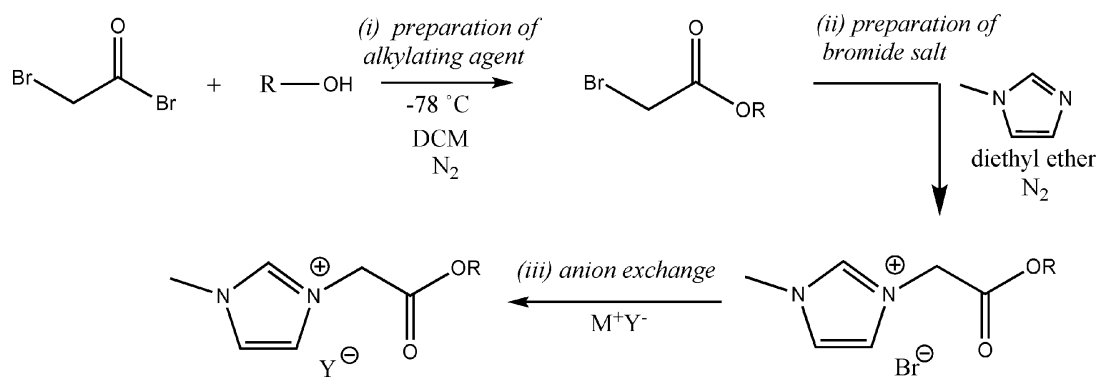

Fig. 2 2-Step synthesis of IL followed by anion exchange. 
Table 1 IL data

\section{IL Cation}

(1)

$\%$ yield

Melting point

$\mathrm{Br}^{-}$

$\mathrm{NTf}_{2}^{-}$

$\mathrm{BF}_{4}^{-}$

$\mathrm{PF}_{6}^{-}$

$\mathrm{N}(\mathrm{CN})_{2}{ }^{-}$

$\mathrm{OctOSO}_{3}{ }^{-}$

(1)

$1 \mathbf{a}$

82

$\mathbf{1 b}$
86

liquid

$\begin{array}{ll}\mathbf{1 c} & \mathbf{1 d} \\ 97 & 93\end{array}$

liquid

liquid

$1 \mathrm{e}$
87

liquid

$1 f$

$\underbrace{N}_{0} \overbrace{N}^{\infty}$

$2 \mathbf{a}$

97

2b

liquid

93

2c

liquid

95
liquid

2d

liquid

$2 \mathrm{e}$

98.

liquid<smiles>COCCOC(=O)C[n+]1ccn(C)c1</smiles>

$3 \mathbf{a}$
89

53-55 ${ }^{\circ} \mathrm{C}$

3b

91

$3 c$

liquid

liquid

3d

$58-60{ }^{\circ} \mathrm{C}$

$3 \mathbf{e}$

80

$3 f$

4<smiles>CCOCCOC(=O)C[n+]1ccn(C)c1</smiles>

$4 \mathbf{a}$
93

24-26 ${ }^{\circ} \mathrm{C}$

$4 \mathrm{~b} \quad \mathbf{4 c}$

$5 a$

$\underbrace{n}$

88

$25-27^{\circ} \mathrm{C}$

90

liquid

$\mathbf{4 c}$
96

4d

liquid

98

$4 e$
99

liquid

2 f

96.

$\begin{array}{lll}\mathbf{5 b} & \mathbf{5 c} & \mathbf{5 d} \\ 68 & 97 & 97\end{array}$<smiles></smiles>

$6 a$

89

$28-30{ }^{\circ} \mathrm{C}$

liquid

liquid

liquid

5 e

liquid

6d

6b $\quad 6 c$

84

liquid

95

liquid

6e

51

7d

$7 \mathbf{a}$
97

$7 \mathbf{b}$

$\overbrace{0}^{+}$

52-54 ${ }^{\circ}$

$7 c$

94

liquid

liquid

liquid

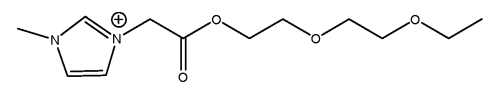

$8 \mathbf{a}$
92

$28-30{ }^{\circ} \mathrm{C}$

$8 b$

87

liquid

$8 c$

96

8d
96

liquid

liquid

(1)

$9 a$
98

32-34 ${ }^{\circ} \mathrm{C}$

9b

82

9c

93

\section{9d}

liquid

liquid

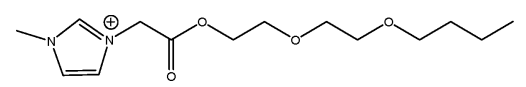

10a

94

$48-50{ }^{\circ} \mathrm{C}$

10b

86

liquid

10c

92

liquid

10d

$11 \mathrm{a}$

$\overbrace{0}^{N} \overbrace{0}^{O}$

55

59-61 ${ }^{\circ} \mathrm{C}$

11b

93

\section{1c}

94

$12 \mathrm{a}$

51

$49-51^{\circ} \mathrm{C}$

12b

事

$13 a$

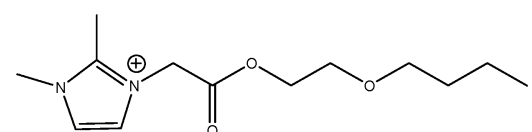

92

liquid

13b

83

liquid

13c

95

liquid

110

57.

$14 a$

88
$74-75$

14b

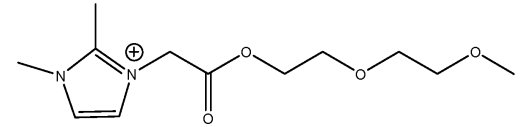

96

liquid

$14 \mathrm{c}$

94

15a
81
liquid

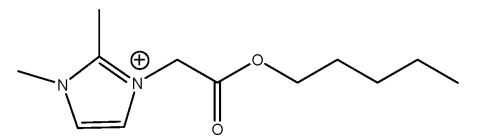

15b

95
liquid

$15 \mathrm{c}$

93

liquid

/a

$\mathrm{n} / \mathrm{a}$

liquid

$7 e$
94

liquid

$7 \mathbf{f}$

82
liquid

8 e

99

liquid

8 f

$\mathbf{8 f}$
93

$\begin{array}{ll}\mathbf{9 e} & \mathbf{9 f} \\ 85 & 98\end{array}$

liquid

liquid

\section{$10 \mathrm{e}$}

98

$34-36{ }^{\circ} \mathrm{C}$

$10 \mathrm{f}$

liquid

\section{$11 \mathrm{e}$}

75

liquid

$11 f$

84

liquid

liquid

13d

97

liquid

14d

95

liquid

15d

97

$40-42{ }^{\circ} \mathrm{C}$ $\mathrm{n} / \mathrm{a}$

$12 \mathrm{f}$

79

liquid

$\begin{array}{ll}\mathbf{1 3 e} & \mathbf{1 3 f} \\ 78 & 84\end{array}$

liquid $\quad 50-52{ }^{\circ} \mathrm{C}$

$14 \mathrm{e} \quad 14 \mathrm{f}$

$99 \quad 94$

liquid liquid

$15 \mathrm{e} \quad 15 \mathrm{f}$

$85 \quad 86$

liquid $63-65^{\circ} \mathrm{C}$ 
method of anion exchange was used to prepare the hexafluorophosphates, in which the 3-substituted 1-methyl imidazolium bromide salt was refluxed in acetone for four days in the presence of potassium hexafluorophosphate to give the $\mathrm{PF}_{6}{ }^{-}$ILs in high yields $(>90 \%)$. The $\mathrm{BF}_{4}^{-}$ILs were synthesized analogously to the $\mathrm{PF}_{6}{ }^{-}$salts using sodium tetrafluoroborate, giving ILs in equally good yields $(>90 \%)$. The corresponding $\mathrm{N}(\mathrm{CN})_{2}^{-}$ salts were again formed by reaction of the bromide IL with the sodium salt for four days, however the solvent was changed from acetone to acetonitrile and refluxing was unnecessary, with good yields (51-99\%) of exchanged dicyanoamide IL obtained even at $20^{\circ} \mathrm{C}$. 'To obtain the IL octylsulfate, the bromide salt of the IL and sodium octylsulfate were stirred in water for 2 hours at $60{ }^{\circ} \mathrm{C}$, according to the literature method. ${ }^{43}$ The water was then slowly removed under vacuum. The resulting precipitate was subsequently dissolved in dichloromethane and washed with a small amount of distilled water. After evaporation of the solvent, the exchanged octylsulfate ILs were obtained in good yields, usually between 80 and $98 \%$. Although two of the octylsulfate ILs (13f and $\mathbf{1 5 f}$ ) are solids at $20^{\circ} \mathrm{C}$, they still exhibit melting points significantly below $100{ }^{\circ} \mathrm{C}$ (Table 1). A study of hydrogenation $v s$. hydrogenolysis of benzyl cinnamate in ILs ( $\mathbf{2 b}$, $\mathbf{3 b}, \mathbf{4 b}, \mathbf{5 b}, \mathbf{6 b}, \mathbf{9 b}, \mathbf{1 1 b}$ and $\mathbf{1 5 b}$; $2 \mathrm{f}$ and $\mathbf{5 f}$ ) prepared above has recently been reported by Gathergood et $\mathrm{al}^{44}$

\section{Preparation of amide ILs}

The method of preparation of the amide ILs is analogous to that for the ester derivatives. The only notable difference was that in the case of 19a recrystallisation from diethyl ether was used to purify the intermediate bromoacetamide, rather than vacuum distillation. Good yields were obtained for the majority of the bromide and octylsulfate amide derivatives, with elevated melting points again recorded for the bromide salts (Table 2).

Although the 3-methoxypropylamide and bis(2-methoxyethyl)amide 3-methylimidazolium bromide salts (19a and 20a, respectively) were solids at $20^{\circ} \mathrm{C}$, they both had melting points under $100{ }^{\circ} \mathrm{C}$, technically qualifying them as ionic liquids. However, the pyrrolidine amide 3-methylimidazolium 16a and 2,3-dimethylimidazolium bromide 17a salts had melting points above $100{ }^{\circ} \mathrm{C}$ and hence were not classified as ionic liquids. In contrast, 2-methoxyethyl 3-methylimidazolium bromide was a liquid at $20^{\circ} \mathrm{C}$, as were octylsulfates $\mathbf{1 6 f}$ and $\mathbf{2 0 f}$, derived from 16a and 20a by the previous anion-exchange process.

\section{Toxicity}

Seven strains of bacteria were used to assess the antimicrobial activity of the ILs: 4 Gram negative (Pseudomonas aeruginosa, Escherichia coli, Klebsiella sp., Salmonella sp.) and three Gram positive (Staphylococcus aureus, Enterococcus sp., Bacillus subtilis) organisms.

The minimum inhibitory concentrations were measured for those ILs that showed activity against any of the seven strains. A wide concentration range was tested $(0-20 \mathrm{mg} / \mathrm{mL})$. The MIC values for typical cationic antiseptic/antibacterial agents generally lie in the range of $8 \mu \mathrm{g} / \mathrm{mL}$ to $500 \mu \mathrm{g} / \mathrm{mL}^{45}$ The commercial disinfectants, BAC (benzalkonium chloride, a mixture of quaternary ammonium salts with hydrocarbon chains of $8,10,12,14,16$ and 18 atoms length) and CPC
Table 2 Amide IL data

Amide (cation)

$\%$ yield

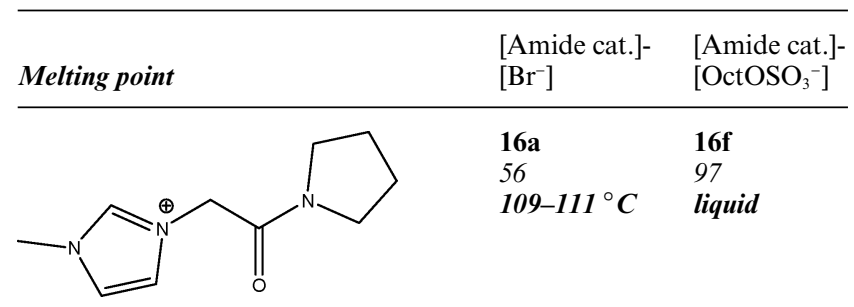<smiles></smiles>

$17 \mathrm{a} \quad \mathbf{1 7 f}$

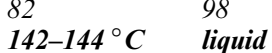

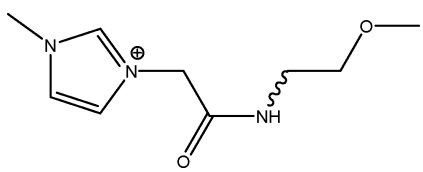

18a
97
liquid
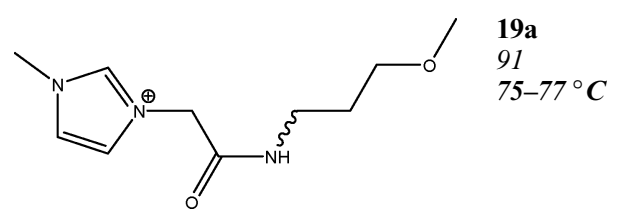

$\mathrm{n} / \mathrm{a}$

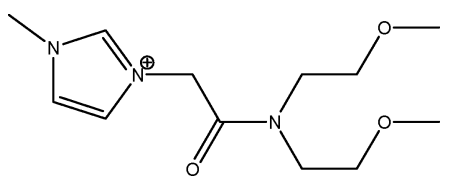

20a

68-70 ${ }^{\circ} \mathrm{C}$

$20 f$

92

liquid

(cetylpyridinium chloride, a pyridinium salt with a 16-carbon aliphatic chain) both have reported MIC values of $8 \mu \mathrm{g} / \mathrm{mL}$ for S. aureus 209, S. aureus R209 and B. subtilis. In the case of CPC, which is a discrete entity, having a molecular mass of $340 \mathrm{Da}$, this represents a MIC of $23.5 \mu \mathrm{M}$. Ionic liquids with long hydrocarbon chains also exhibit toxic properties, with the C-12-substituted 1-methyl-3-dodecylimidazolium bromide (MIC from $8 \mu \mathrm{g} / \mathrm{mL}$ to $32 \mu \mathrm{g} / \mathrm{mL}^{45}$ i.e. 24.2 to $96.7 \mu \mathrm{M}$ ) and especially C-14/C-16 showing pronounced biocidal properties (1-methyl-3-tetradecylimidazolium chloride/1-methyl-3hexadecylimidazolium bromide - MICs from $4 \mu \mathrm{g} / \mathrm{mL}$ to $8 \mu \mathrm{g} / \mathrm{mL},{ }^{45}$ (12.7 to $25.4 \mu \mathrm{M}$, C- $14 / 10.3$ to $20.7 \mu \mathrm{M}, \mathrm{C}-16$ ) over a range of 10 bacteria and 2 fungi). The $\mathrm{C}-10$ chain ionic liquid, 1-methyl-3-decylimidazolium chloride is also a good antiseptic, with MIC values of $8 \mu \mathrm{g} / \mathrm{mL}(30.9 \mu \mathrm{M})$ for $\mathrm{E}$. coli, $16 \mu \mathrm{g} / \mathrm{mL}(61.8 \mu \mathrm{M})$ for S. aureus 209 , and $32 \mu \mathrm{g} / \mathrm{mL}$ $(123.6 \mu \mathrm{M})$ for S. aureus R209. Higher MICs were recorded for S. typhimurium and B. subtilis (both $125 \mu \mathrm{g} / \mathrm{mL}$, i.e. $482.9 \mu \mathrm{M}$ ) and fungal strains C. albicans and C. regularis (both $250 \mu \mathrm{g} / \mathrm{mL}$, $965.9 \mu \mathrm{M}){ }^{45} \mathrm{In}$ fact imidazolium ionic liquids in which an ester linkage is used to attach a hydrocarbon chain (C-1 to 18) to the cationic core have recently been the subject of a patent application for anti-microbial compositions in the preservation of personal care products and cosmetics. ${ }^{42}$ In contrast, a number of our ILs containing ethereal side-chains linked via an ester to 
the imidazole core exhibited no toxicity even at concentrations above $20 \mathrm{mg} / \mathrm{mL}$, against any of 7 bacterial strains screened. Non-toxicity across a broad range of microorganisms has also been reported by Pernak, who synthesized 1-alkylimidazolium DL-lactates (5 examples, alkyl varying from methyl to pentyl) with MIC values $>5.814 \mathrm{mM}$ across a range of 5 Gram-negative rods, 5 Gram-positive cocci and 2 fungal strains. ${ }^{16}$ For our nontoxic ILs, MIC values greater than $20 \mathrm{mg} / \mathrm{mL}$ correspond to a lack of toxicity at concentrations from $>27 \mathrm{mM}$ to $>75 \mathrm{mM}$, depending on the molecular mass of the IL. In most cases, all 7 bacterial strains showed no sensitivity towards each IL (MIC is quoted as $>$ test concentration when no toxicity was shown at the concentration tested). These data are summarised in Table 3.

A toxicity study with the ester, 1-methyl-3-(decyloxycarbonyl)methylimidazolium bromide (12a) which is known to exhibit toxicity due to its long alkyl chain, was completed as a reference. This experiment compares, for the same side chain length, the impact of the presence of the ether oxygens (in 11a) on toxicity. As expected 12a was toxic to all the different bacteria screened (Table 4), and in some cases even at low concentrations (Table 4 E. coli, Enterococcus sp. and $S$. aureus). A comparison of the results in Table 4 with those from Table 3, (11a), indicates that the presence of oxygen in the side chain is crucial to suppress the toxicity.

From the data collected it is apparent that all the bromide salts with an oxygenated side chain are non-toxic. At the forefront of our results is the fact that IL series $\mathbf{1}$ and $\mathbf{2}$ (which lack ethereal side-chains) are the most toxic tested in this study (each showing toxicity with 3 different anions). These ILs, which have highly lipophilic cations, are the only ones to display toxicity with three different anions. The lipophilic octylsulfate salts (1f, 8f, 10f, 13f, 14f) together with the $\mathrm{NTf}_{2}^{-}(\mathbf{1 b}, \mathbf{2 b}, \mathbf{3 b}, \mathbf{5 b}, \mathbf{7 b})$ salts were among the most toxic imidazolium salts studied, showing the highest number of ILs with MIC values in the range $2.5-10 \mathrm{mg} / \mathrm{mL}$.

Results from the $\mathrm{BF}_{4}{ }^{-}$series provided further evidence for the toxicity of an alkyl chain, with the only toxic examples out of all the $\mathrm{BF}_{4}{ }^{-}$salts occurring in cases $2 \mathrm{c}$ and $\mathbf{1 5 c}$ (both containing pentyl ester side-chains without ether linkages). A similar trend was observed for the $\mathrm{N}(\mathrm{CN})_{2}{ }^{-}$salts in which only butyl (1e) and pentyl (2e) esters exhibited toxicity. However, a notable exception was observed when incorporation of a methyl group at $\mathrm{C}-2$ of the imidazole ring in pentyl ester $\mathbf{1 5 e}$ abolished the toxicity previously recorded for C-2 unsubstituted pentyl ester $\mathbf{2 e}$.

As previously mentioned, toxicity is frequently encountered with ionic liquids containing an extended hydrocarbon chain. Notably, Bodor et al. ${ }^{46-50}$ had shown that a long chain ester derivative of methyl imidazole (compound 21 in Fig. 3) shows effective antimicrobial activity at ppm concentrations.

The results in Table 3 show that all the ionic liquids prepared show significantly lower toxicity than derivatives without ester and ether or poly ether functional groups. ILs 17a, 19a, 20a and $20 \mathrm{f}$ demonstrate that the presence of oxygen atoms in the

Table $3 \mathrm{MIC}^{a}$ values (low toxicities [high MIC] were recorded for all bacterial strains)

\begin{tabular}{|c|c|c|c|c|c|c|c|c|c|c|c|c|c|c|c|c|c|c|c|}
\hline Strain & Coun & er Ani & & & & & & & & & & & & & & & & & \\
\hline \multirow[t]{2}{*}{ (I-VII) } & \multicolumn{19}{|c|}{ Bromide } \\
\hline & $\begin{array}{l}\mathbf{1 a} \\
>72\end{array}$ & $\begin{array}{l}\mathbf{2 a} \\
>69\end{array}$ & $\begin{array}{l}\mathbf{3 a} \\
>72\end{array}$ & $\begin{array}{l}\mathbf{4 a} \\
>68\end{array}$ & $\begin{array}{l}\mathbf{5 a} \\
>65\end{array}$ & $\begin{array}{l}\mathbf{6 a} \\
>62\end{array}$ & $\begin{array}{l}7 \mathbf{a} \\
>62\end{array}$ & $\begin{array}{l}\mathbf{8 a} \\
>59\end{array}$ & $\begin{array}{l}\mathbf{9 a} \\
>60\end{array}$ & $\begin{array}{l}\mathbf{1 0 a} \\
>55\end{array}$ & $\begin{array}{l}\text { 11a } \\
>54\end{array}$ & $\begin{array}{c}\text { 13a } \\
>60\end{array}$ & $\begin{array}{c}\mathbf{1 4 a} \\
>59\end{array}$ & $\begin{array}{c}15 \mathbf{a} \\
>66\end{array}$ & $\begin{array}{l}\mathbf{1 6 a} \\
>73\end{array}$ & $\begin{array}{c}17 \mathbf{a} \\
>69\end{array}$ & $\begin{array}{c}\mathbf{1 8 a} \\
>72\end{array}$ & $\begin{array}{c}19 a \\
>68\end{array}$ & $\begin{array}{l}\mathbf{2 0 a} \\
>60\end{array}$ \\
\hline \multirow[t]{3}{*}{ (I-VII) } & \multicolumn{19}{|c|}{ Trifluoromethanesulfonimide } \\
\hline & 1b & $\mathbf{2 b}$ & 3b & $4 b$ & $5 \mathbf{b}$ & $\mathbf{6 b}$ & $7 \mathrm{~b}$ & $\mathbf{8 b}$ & $9 b$ & $10 \mathrm{~b}$ & 11b & 13b & 14b & $15 b$ & $16 \mathrm{~b}$ & & & & \\
\hline & 21 & 20 & 21 & $>41$ & 19 & $>38$ & 19 & $>37$ & $>36$ & $>35$ & $>35$ & $>37$ & $>37$ & $>40$ & $\mathrm{n} / \mathrm{a}$ & & & & \\
\hline (I-VII) & \multicolumn{19}{|c|}{ Tetrafluoroborate } \\
\hline \multirow[t]{2}{*}{ (I-VII) } & \multicolumn{19}{|c|}{ Hexafluorophosphate } \\
\hline & $\begin{array}{l}\text { 1d } \\
>58\end{array}$ & $\begin{array}{l}\mathbf{2 d} \\
>56\end{array}$ & $\begin{array}{l}\mathbf{3 d} \\
>58\end{array}$ & $\begin{array}{l}\mathbf{4 d} \\
>56\end{array}$ & $\begin{array}{l}\mathbf{5 d} \\
>54\end{array}$ & $\begin{array}{l}\mathbf{6 d} \\
>52\end{array}$ & $\begin{array}{l}7 \mathbf{d} \\
6.4\end{array}$ & $\begin{array}{l}\mathbf{8 d} \\
>50\end{array}$ & $\begin{array}{l}\mathbf{9 d} \\
>48\end{array}$ & $\begin{array}{l}\mathbf{1 0 d} \\
>47\end{array}$ & $\begin{array}{l}\mathbf{1 1 d} \\
>46\end{array}$ & $\begin{array}{c}\mathbf{1 3 d} \\
>50\end{array}$ & $\begin{array}{c}\mathbf{1 4 d} \\
>50\end{array}$ & $\begin{array}{c}\mathbf{1 5 d} \\
>54\end{array}$ & $\begin{array}{l}\text { 16d } \\
\mathrm{n} / \mathrm{a}\end{array}$ & & & & \\
\hline \multirow[t]{3}{*}{ (I-VII) } & \multicolumn{19}{|c|}{ Dicyanoamide } \\
\hline & $1 e$ & $2 e$ & $3 e$ & $4 e$ & $5 e$ & 6e & $7 e$ & $8 \mathbf{e}$ & $9 e$ & $10 \mathrm{e}$ & $11 \mathrm{e}$ & $13 \mathrm{e}$ & $14 \mathrm{e}$ & $15 \mathrm{e}$ & $16 \mathrm{e}$ & & & & \\
\hline & 19 & 36 & $>75$ & $>72$ & $>68$ & $>65$ & $>65$ & $>62$ & $>59$ & $>57$ & $>57$ & $>28$ & $>28$ & $>30$ & $\mathrm{n} / \mathrm{a}$ & & & & \\
\hline (I-VII) & \multicolumn{19}{|c|}{ Octylsulfates } \\
\hline
\end{tabular}

${ }^{a}$ In $\mathrm{mM}$, the number of microorganisms in $1 \mathrm{~mL}$ range from $10^{4}$ to $10^{5} \mathrm{n} / \mathrm{a}$ indicates compound was not synthesized.

Table 4 Percentage kill for seven strains of bacteria at various concentrations of 12a

\section{2a Concentration $(\mu \mathrm{g} / \mathrm{mL})$}

\begin{tabular}{|c|c|c|c|c|c|c|c|c|c|}
\hline \multirow[b]{2}{*}{ Strain (I-VII) } & \multirow{2}{*}{$\frac{1000}{2.8 \mathrm{mM}}$} & \multirow{2}{*}{$\frac{500}{1.4 \mathrm{mM}}$} & \multirow{2}{*}{$\frac{250}{692.6 \mu M}$} & \multirow{2}{*}{$\frac{125}{346.3 \mu \mathrm{M}}$} & \multirow{2}{*}{$\frac{63}{173.2 \mu M}$} & \multirow{2}{*}{$\frac{31.5}{86.6 \mu \mathrm{M}}$} & \multirow{2}{*}{$\frac{15.75}{43.3 \mu \mathrm{M}}$} & \multirow{2}{*}{$\frac{7.88}{21.6 \mu \mathrm{M}}$} & \multirow{2}{*}{$\frac{3.94}{10.8 \mu \mathrm{M}}$} \\
\hline & & & & & & & & & \\
\hline (I) E. coli & 91 & 82 & 92 & 92 & 37 & 28 & 17 & 9 & 10 \\
\hline (II) Enterococcus sp. & 96 & 84 & 83 & 50 & 49 & 19 & 23 & 6 & 7 \\
\hline (III) $P$. aeruginosa & 100 & 82 & 82 & 56 & 0 & 6 & 0 & 0 & 0 \\
\hline (IV) Salmonella sp. & 86 & 88 & 74 & 58 & 10 & 0 & 0 & 0 & 0 \\
\hline (V) Klebsiella sp. & 92 & 68 & 64 & 21 & 7 & 0 & 0 & 0 & 0 \\
\hline (VI) $S$. aureus & - & 96 & 94 & 81 & 90 & 86 & 88 & 90 & 66 \\
\hline (VII) B. subtilis & 100 & 83 & 82 & 80 & 0 & 0 & 0 & 0 & 0 \\
\hline
\end{tabular}


<smiles>CCCCCCCCCCCC(=O)OC[n+]1ccn(C)c1</smiles><smiles>CCCCCCCCCCOC(=O)C[n+]1ccn(C)c1</smiles>

$12 \mathbf{a}$

Fig. 3 Comparison of structures of 21 1-[(n-undecylcarbonyloxy)methyl]-3-methylimidazolium chloride and 12a (3-methyl-1-(n-decyloxycarbonylmethyl) imidazolium bromide. Both are potent antibacterials.

side chain of amide derivatives also leads to low toxicity ILs, when compared with ILs containing hydrocarbon side-chains of similar length. (e.g. If 20a is compared with dodecyl substituted imidazolium salts vide supra). These results have significant implications for the usefulness of the ILs, as the toxicity is exceptionally low.

\section{Biodegradability}

$\mathrm{CO}_{2}$ Headspace test. To evaluate the biodegradability of the test ionic liquids, the " $\mathrm{CO}_{2}$ Headspace" test (ISO 14593) $)^{51}$ was implemented. This method allows the evaluation of the ultimate aerobic biodegradability of an organic compound in an aqueous medium at a given concentration of microorganisms by analysis of inorganic carbon. The test ionic liquid, as the sole source of carbon and energy, was added at a concentration of $40 \mathrm{mg} \mathrm{L}^{-1}$ to a mineral salt medium. These solutions were inoculated with activated sludge collected from an activated sludge treatment plant, washed and aerated prior to use and incubated in sealed vessels with a headspace of air. Biodegradation (mineralization to carbon dioxide) was determined by measuring the net increase in total organic carbon (TOC) levels over time.

Biodegradation data. Results for biodegradation of the octylsulfates at weekly intervals over 28 days are tabulated in the ESI $\dagger$ and represented graphically in Figs. 4-6.

ILs, 2f, 5f, 6f, 9f, $10 f$ and $\mathbf{1 3 f}$ passed the $\mathrm{CO}_{2}$ Headspace test (at least $60 \%$ over 28 days duration) and clearly are "readily biodegradable" according to this test (see Fig. 4 and Fig. 5). ILs 1f, 3f, 4f, 7f, and $8 f$ all show significant biodegradation (between 55-59\% in $\mathrm{CO}_{2}$ Headspace test) and represent a marked improvement over the negligible biodegradation result obtained for the imidazolium based ILs, $\left[\mathrm{bmim}^{-}\right]\left[\mathrm{BF}_{4}\right]$ and $[$ bmim $]\left[\mathrm{PF}_{6}\right]^{31,33,34} \mathrm{~A}$ decrease in biodegradation potential can be seen for the amide ILs, with none surpassing a threshold of $40 \%$ in the $\mathrm{CO}_{2}$ Headspace test after 28 days (Fig. 6). This fact emphasises the importance of an ester linkage for successful biodegradation of these imidazolium ILs.

\section{Conclusions}

Several factors that are important in the development of green solvents for industry are melting point, toxicity and biodegradation. We have demonstrated that for a series of ionic liquids containing a wide range of ether and poly ether esters

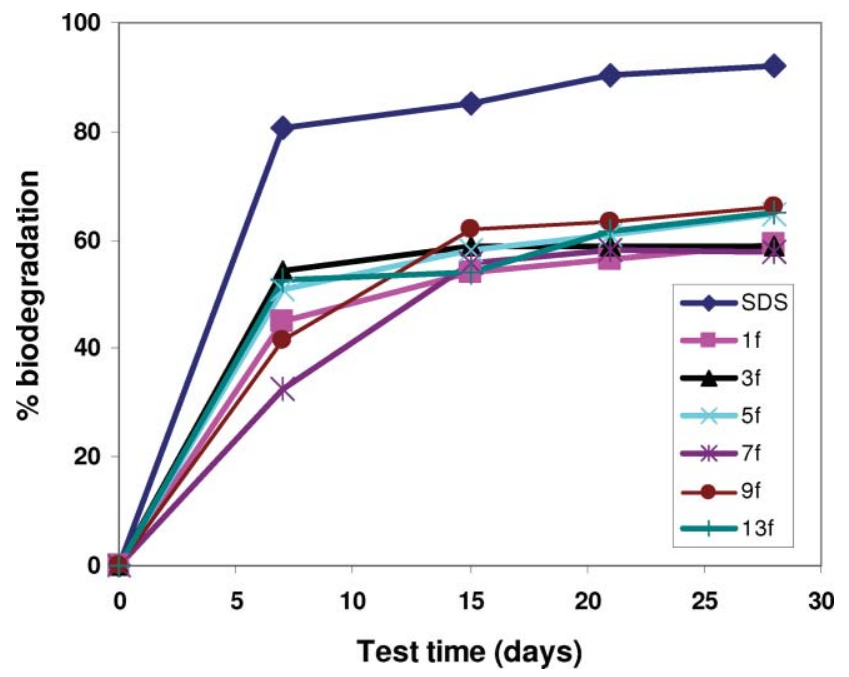

Fig. 4 Biodegradation of selected ILs.

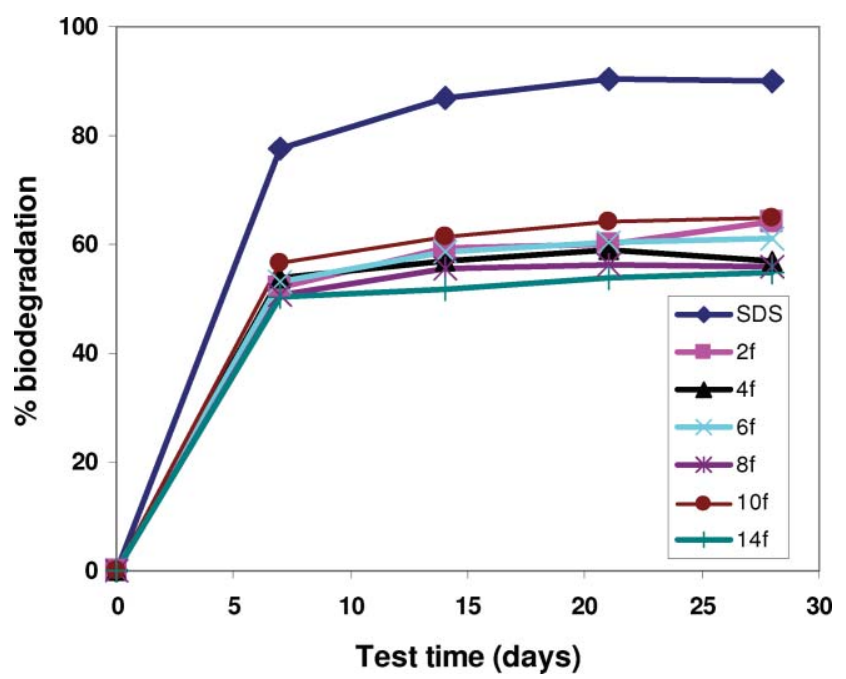

Fig. 5 Biodegradation of selected ILs.

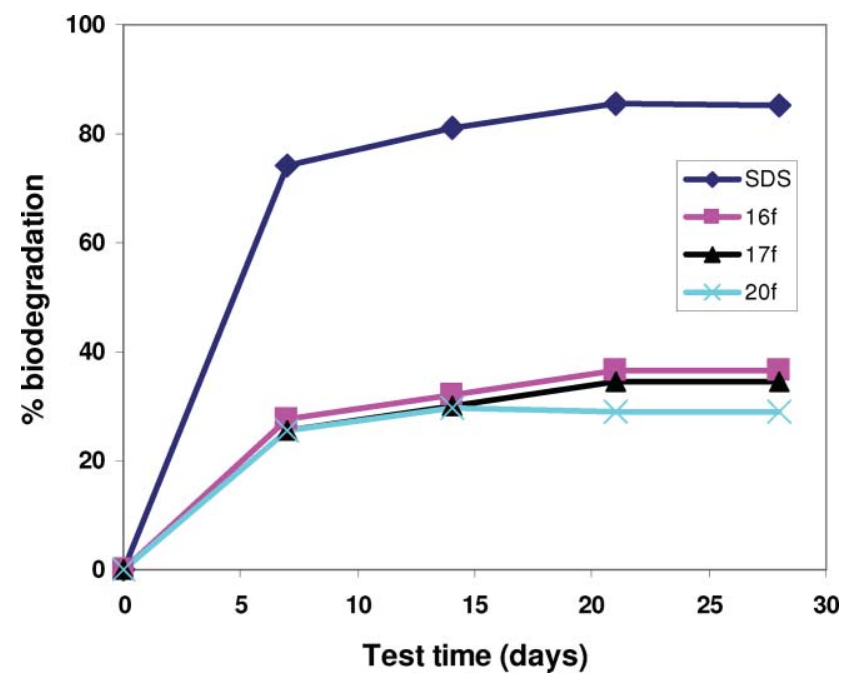

Fig. 6 Biodegradation of selected ILs. 
many are liquid at room temperature and all have melting points below $100{ }^{\circ} \mathrm{C}$. Examples containing extended poly ether side chains, e.g. 9b-f, are liquid at room temperature. Toxicity studies show a clear trend that for all the ionic liquids prepared containing ether or poly ether side-chains a significant reduction in toxicity is observed, compared with the long chain alkyl substituted derivatives. 9a-f and 10a-f contain extended side-chains but nevertheless show no antimicrobial toxicity even at concentrations above $20 \mathrm{mg} / \mathrm{mL}$ (36-59 and 20-57 mM respectively, depending on molecular mass). Biodegradation results support previous studies demonstrating that an ester group is preferred over an amide. Whilst ILs with a butoxyor propoxy- terminus are readily biodegradable, those with methoxy- or ethoxy- terminal substitution remained slightly below the $60 \%$ threshold for biodegradability.

\section{Experimental}

All chemicals were purchased from Aldrich, with the exception of lithium trifluoromethanesulfonimide, which was purchased from Solvionic. 1-Methylimidazole and bromoacetyl bromide were used without further purification. 1-Butanol, 1-pentanol, 2-(2-methoxyethoxy) ethanol, 2-(2ethoxyethoxy) ethanol, 2-(2-propoxyethoxy) ethanol, 2-(2butoxyethoxy) ethanol, 2-methoxyethanol, 2-ethoxyethanol, 2propoxyethanol, 2-butoxyethanol, and 1-decanol were dried over $4 \AA$ A molecular sieves and used without further purification. 1,2-Dimethylimidazole was distilled before use. All organic solvents were dried and distilled before use. All NMR spectra of ILs were recorded in deuterated chloroform, acetonitrile or acetone on a Bruker $400 \mathrm{MHz}$ spectrometer.

A representative synthetic method is given for each group of compounds prepared. All other information may be found in the ESI. $\dagger$

\section{$\mathrm{CO}_{2}$ Headspace test}

To evaluate the biodegradability of the test ionic liquids, the " $\mathrm{CO}_{2}$ Headspace" test (ISO 14593) was also applied. ${ }^{52}$ This method allows the evaluation of the ultimate aerobic biodegradability of an organic compound in aqueous medium at a given concentration of microorganisms by analysis of inorganic carbon. The test ionic liquid, as the sole source of carbon and energy, was added at a concentration of $40 \mathrm{mg} \mathrm{L}^{-1}$ to a mineral salt medium. These solutions were inoculated with activated sludge collected from an activated sludge treatment plant, washed and aerated prior to use and incubated in sealed vessels with a headspace of air. Biodegradation (mineralization to carbon dioxide) was determined by measuring the net increase in total organic carbon (TOC) levels over time compared with blanks. Sodium n-dodecyl sulfate (SDS) was used as a reference substance. The tests ran for 28 days and the extent of biodegradation was expressed as a percentage of the theoretical amount of inorganic carbon, based on the amount of test compound added at the start. $\mathrm{CO}_{2}$ was estimated by $\mathrm{GC}$ according to the equation:

$$
\begin{aligned}
\% \mathrm{CO}_{2}(\text { headspace }) & =\frac{\left(\mathrm{GC} \mathrm{peak} \mathrm{height}_{\text {sample }}-\mathrm{GC}_{\text {peak height }}{ }_{\text {air }}\right)}{\mathrm{GC} \text { peak height }}{ }_{\text {standard }} \\
& \times \% \mathrm{CO}_{2}(\text { standard })
\end{aligned}
$$

\section{Toxicity studies}

Minimum inhibitory concentrations (MICs) for the compounds were determined by serial two-fold dilutions in Mueller-Hinton broth using the broth microdilution method described by Amsterdam. ${ }^{52}$

Strains were grown in Mueller-Hinton broth overnight. The compound solution and 96-well plates were ready before the cultures reached the desired growth phase. The compound to be tested was dissolved in sterile water and diluted in the test medium to twice the maximum concentration desired in the test, i.e., the highest desired concentration was $20 \mathrm{mg} / \mathrm{mL}$, so the ionic liquid was diluted to $40 \mathrm{mg} / \mathrm{mL}$.

$\mu \mathrm{L}$ of Mueller-Hinton broth was dispensed into all wells of a microtitre plate. $100 \mu \mathrm{L}$ of the $2 \times$ compound solution was pipetted into the wells in column 1 (far left of plate). The compound was mixed into the wells in column 1 by pipetting up and down 6-8 times. $100 \mu \mathrm{L}$ was withdrawn from column 1 and added to column 2 . This made column 2 a two-fold dilution of column 1. This was mixed up and down $6-8$ times. $100 \mu \mathrm{L}$ was transferred to column 3 . This procedure was repeated down to column 10 only. $100 \mu \mathrm{L}$ was discarded from column 10 rather than putting it in column $11.5 \mu \mathrm{L}$ of $\left(2 \times 10^{4} \mathrm{CFU} / \mathrm{mL}\right)$ the strain to be tested was dispensed into wells in the columns 11 to 1 in that order. Column 12 was used as a sterility control. The plates were incubated at $37^{\circ} \mathrm{C}$. Growth on the plates was noted and recorded after 18-36 hours. The MIC was the lowest concentration of the compound that completely inhibited growth of the organism in the microdilution wells as detected by the unaided eye.

Compounds that were water-insoluble were diluted in methanol. The MICs for these compounds were obtained using the same procedure described above. However, instead of diluting the compound directly in Mueller-Hinton broth, $20 \mu \mathrm{L}$ of the solution (to give a final concentration of $20 \mathrm{mg} / \mathrm{mL}$ ) was added to the first well in the row. The methanol was allowed to evaporate and then $200 \mu \mathrm{L}$ of Mueller-Hinton broth was added, mixed and diluted using serial two-fold dilutions as described above.

\section{Preparation of 2-propoxyethyl 2-bromoacetate}

To a stirred solution of dichloromethane $(350 \mathrm{~mL})$, propoxyethanol $(47.84 \mathrm{~mL}, 460 \mathrm{mmol})$, and triethylamine (69.3 $\mathrm{mL}, 500 \mathrm{mmol})$, under a nitrogen atmosphere at $-78{ }^{\circ} \mathrm{C}$ was added dropwise bromoacetyl bromide (92.92 g, $460 \mathrm{mmol}$ ). After stirring at $-78^{\circ} \mathrm{C}$ for $3 \mathrm{~h}$, the reaction mixture was allowed to warm up to $-20{ }^{\circ} \mathrm{C}$ and quenched by addition of water $(50 \mathrm{~mL})$. The organic phase was washed with distilled water $(3 \times$ $25 \mathrm{~mL})$, saturated ammonium chloride $(3 \times 25 \mathrm{~mL})$, saturated sodium bicarbonate $(3 \times 25 \mathrm{~mL})$ and brine $(2 \times 25 \mathrm{~mL})$. The organic phase was then dried over magnesium sulfate, filtered and solvents removed via rotary evaporation. The crude product was distilled (bp $100-102{ }^{\circ} \mathrm{C}$ ) to give a pale yellow liquid in $83 \%$ yield $(85.91 \mathrm{~g}, 382 \mathrm{mmol})$.

${ }^{1} \mathrm{H} \mathrm{NMR}\left(400 \mathrm{MHz}, \mathrm{CDCl}_{3}\right) \delta(\mathrm{ppm}) 4.34(\mathrm{t}, J=4.6 \mathrm{~Hz}, 2 \mathrm{H})$, $3.88(\mathrm{~s}, 2 \mathrm{H}), 3.67(\mathrm{t}, J=4.6 \mathrm{~Hz}, 2 \mathrm{H}), 3.47(\mathrm{t}, J=6.9 \mathrm{~Hz}, 2 \mathrm{H})$, $1.66(\mathrm{tq}, J=6.9,7.3 \mathrm{~Hz}, 2 \mathrm{H}), 0.94(\mathrm{t}, J=7.3 \mathrm{~Hz}, 3 \mathrm{H})$.

${ }^{13} \mathrm{C} \mathrm{NMR}\left(100 \mathrm{MHz}, \mathrm{CDCl}_{3}\right) \delta(\mathrm{ppm}) 167.31,73.07,68.10$, $65.42,25.90,22.81,10.52$. 
Preparation of 3-methyl-1-(2-(2-n-propoxyethoxy)ethoxycarbonylmethyl) imidazolium bromide (9a)

To a stirred solution of 1 -methylimidazole $(50 \mathrm{mmol}, 4.10 \mathrm{~g})$ in diethyl ether $(100 \mathrm{~mL})$ at $-15^{\circ} \mathrm{C}$ under a nitrogen atmosphere was added dropwise 2-(2-propoxyethoxy)ethyl-2-bromoacetate $(60 \mathrm{mmol}, 16.14 \mathrm{~g})$. The reaction mixture was stirred vigorously at $-15^{\circ} \mathrm{C}$ for $3 \mathrm{~h}$, then at $20^{\circ} \mathrm{C}$ for $16 \mathrm{~h}$. The diethyl ether phase was decanted and the IL washed with diethyl ether $(2 \times 30 \mathrm{~mL})$, then residual solvent removed on the rotary evaporator. The product was dried under high vacuum for $8 \mathrm{~h}$ yielding a white solid in $98 \%$ yield $(17.16 \mathrm{~g}, 48.89 \mathrm{mmol})$.

${ }^{1} \mathrm{H}$ NMR (400 MHz, $\left.\mathrm{CDCl}_{3}\right) \delta(\mathrm{ppm}) 10.13(\mathrm{~s}, 1 \mathrm{H}), 7.54$, (t, $J=1.8 \mathrm{~Hz}, 1 \mathrm{H}), 7.34(\mathrm{t}, J=1.8 \mathrm{~Hz}, 1 \mathrm{H}), 5.45(\mathrm{~s}, 2 \mathrm{H}), 4.31(\mathrm{t}$, $J=4.6 \mathrm{~Hz}, 2 \mathrm{H}), 4.02(\mathrm{~s}, 3 \mathrm{H}), 3.68(\mathrm{t}, J=4.6 \mathrm{~Hz}, 2 \mathrm{H}), 3.59-3.57$ $(\mathrm{m}, 2 \mathrm{H}), 3.53-3.50(\mathrm{~m}, 2 \mathrm{H}), 3.35(\mathrm{t}, J=6.9 \mathrm{~Hz}, 2 \mathrm{H}), 1.53(\mathrm{tq}$, $J=6.9,7.3 \mathrm{~Hz}, 2 \mathrm{H}), 0.84(\mathrm{t}, J=7.3 \mathrm{~Hz}, 3 \mathrm{H})$.

${ }^{13} \mathrm{C}$ NMR $\left(100 \mathrm{MHz}, \mathrm{CDCl}_{3}\right) \delta(\mathrm{ppm}) 166.21,138.54,123.85$, $122.84,73.10,70.62,69.92,68.55,65.69,50.29,36.93,22.76$, 10.52 .

$\operatorname{MP}\left({ }^{\circ} \mathrm{C}\right) 32-34{ }^{\circ} \mathrm{C}$.

IR (KBr disc) $\left(\mathrm{cm}^{-1}\right) 2959,2926,2859,1751,1558,1639,1495$, 1452.

MS $m / z$, Found 271.1648 $\left[\mathrm{M}-\mathrm{Br}^{-}\right]^{+}$, Calcd. $\mathrm{C}_{13} \mathrm{H}_{23} \mathrm{~N}_{2} \mathrm{O}_{4}$ 271.1658 .

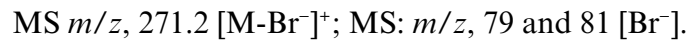

\section{Preparation of 3-methyl-1-(2-(ethoxy)ethoxycarbonylmethyl)} imidazolium $\mathrm{NTf}_{2}^{-}$(4b)

A flask was charged with 3-methyl-1-(2-(ethoxy)ethoxycarbonylmethyl) imidazolium bromide $(2.93 \mathrm{~g}, 10.0 \mathrm{mmol})$ and distilled water $(10 \mathrm{~mL})$. $\operatorname{LiNTf}_{2}(4.59 \mathrm{~g}, 16.0 \mathrm{mmol})$ in distilled water $(3 \mathrm{~mL})$ was added in one portion and the suspension was stirred vigorously for $4 \mathrm{~h}$ at $20^{\circ} \mathrm{C}$. The top aqueous layer was removed and the IL was washed with distilled water $(3 \times$ $10 \mathrm{~mL}$ ). The solvent was then removed on the rotary evaporator and under high vacuum for $8 \mathrm{~h}$ to give a liquid at $20{ }^{\circ} \mathrm{C}$ in $90 \%$ yield (4.42 $\mathrm{g}, 8.97 \mathrm{mmol})$.

${ }^{1} \mathrm{H}$ NMR $\left(400 \mathrm{MHz}, \mathrm{CDCl}_{3}\right) \delta(\mathrm{ppm}) 8.82(\mathrm{~s}, 1 \mathrm{H}), 7.39(\mathrm{t}, J=$ $1.8 \mathrm{~Hz}, 1 \mathrm{H}), 7.34(\mathrm{t}, J=1.8 \mathrm{~Hz}, 1 \mathrm{H}), 5.06(\mathrm{~s}, 2 \mathrm{H}), 4.38(\mathrm{t}, J=$ $4.6 \mathrm{~Hz}, 2 \mathrm{H}), 3.97(\mathrm{~s}, 3 \mathrm{H}), 3.68(\mathrm{t}, J=4.6 \mathrm{~Hz}, 2 \mathrm{H}), 3.56(\mathrm{q}, J=$ $7.1 \mathrm{~Hz}, 2 \mathrm{H}), 1.22(\mathrm{t}, J=7.1 \mathrm{~Hz}, 3 \mathrm{H})$.

${ }^{13} \mathrm{C}$ NMR $\left(100 \mathrm{MHz}, \mathrm{CDCl}_{3}\right) \delta(\mathrm{ppm}) 165.76,137.63,123.80$, $123.25,119.70\left(\mathrm{q}, J=319 \mathrm{~Hz}, 2 C_{3}\right.$ 's), 67.62, 66.67, 65.97, 49.92, 36.56, 15.01 .

IR (thin film on salt plate) $\left(\mathrm{cm}^{-1}\right) 3169,3116,2967,2927,2859$, 1751, 1581, 1569, 1558, 1495, 1452, 1352, 1196, 1135.

MS $m / z, 213.1\left[{\mathrm{M}-\mathrm{NTf}_{2}}^{-}\right]^{+}$; MS: $m / z, 280.0\left[\mathrm{NTf}_{2}{ }^{-}\right]$.

\section{Preparation of 3-methyl-1-(2-(2-methoxyethoxy)- ethoxycarbonylmethyl) imidazolium $\mathrm{PF}_{6}^{-}$(7d)}

A flask was charged with 3-methyl-1-(2-(2-methoxyethoxy)ethoxycarbonylmethyl) imidazolium bromide $(3.55 \mathrm{~g}$, $11.0 \mathrm{mmol})$ and acetone $(10 \mathrm{~mL}) . \mathrm{KPF}_{6}(3.31 \mathrm{~g}, 18.0 \mathrm{mmol})$ in acetone $(5 \mathrm{~mL})$ was added in one portion and the suspension was stirred vigorously for 4 days under reflux. The fine white precipitate was then filtered and washed with acetone $(2 \times$ $5 \mathrm{~mL}$ ). The solvent was removed from the product on the rotary evaporator. The product was then dried under high vacuum for $4 \mathrm{~h}$ to give viscous liquid at $20{ }^{\circ} \mathrm{C}$ in $91 \%$ yield $(3.87 \mathrm{~g}$, $9.97 \mathrm{mmol})$.

${ }^{1} \mathrm{H}$ NMR (400 MHz, $\left.\mathrm{CDCl}_{3}\right) \delta(\mathrm{ppm}) 8.60(\mathrm{~s}, 1 \mathrm{H}), 7.53(\mathrm{tt}$, $J=1.8,1.8 \mathrm{~Hz}, 2 \mathrm{H}), 5.59(\mathrm{~s}, 2 \mathrm{H}), 4.45(\mathrm{t}, J=4.6 \mathrm{~Hz}, 2 \mathrm{H}), 4.00$ $(\mathrm{s}, 3 \mathrm{H}), 3.82(\mathrm{t}, J=4.6 \mathrm{~Hz}, 2 \mathrm{H}), 3.72(\mathrm{t}, J=4.6 \mathrm{~Hz}, 2 \mathrm{H}), 3.62$ $(\mathrm{t}, J=4.6 \mathrm{~Hz}, 2 \mathrm{H}), 3.44(\mathrm{~s}, 3 \mathrm{H})$.

${ }^{13} \mathrm{C} \mathrm{NMR}\left(100 \mathrm{MHz}, \mathrm{CDCl}_{3}\right) \delta(\mathrm{ppm}) 165.98,136.76,123.33$, 123.17, 71.16, 69.69, 67.85, 65.23, 57.54, 49.44, 35.84.

IR (thin film on salt plate) $\left(\mathrm{cm}^{-1}\right) 3172,3124,2926,1751,1580$, 1569, 1559, 1495, 1457, 1218, 1181, 1106.

MS $m / z, 243.2\left[{\mathrm{M}-\mathrm{PF}_{6}}^{-}\right]^{+}$; MS: $m / z, 145.0\left[\mathrm{PF}_{6}{ }^{-}\right]$.

\section{Preparation of 3-methyl-1-(2-(2-n-propoxyethoxy)-} ethoxycarbonylmethyl) imidazolium $\mathrm{BF}_{4}^{-}$(9c)

A dry flask was charged with 3-methyl-1-(2-(2-n-propoxyethoxy)ethoxycarbonylmethyl) imidazolium bromide (2.94 g, $8.38 \mathrm{mmol})$ and acetone $(10 \mathrm{~mL})$ under a nitrogen atmosphere. $\mathrm{NaBF}_{4}(1.11 \mathrm{~g}, 10.1 \mathrm{mmol})$ was added in one portion and the suspension was stirred vigorously for 4 days under reflux. The fine white precipitate was filtered quickly in air and washed with dry acetone $(2 \times 3 \mathrm{~mL})$. The filtrate and washings were combined, solvent removed by rotary evaporation and then under high vacuum to give a slight viscous oil at $20^{\circ} \mathrm{C}$ in $93 \%$ yield $(2.79 \mathrm{~g}$, $7.79 \mathrm{mmol})$.

${ }^{1} \mathrm{H}$ NMR $\left(400 \mathrm{MHz}, \mathrm{CDCl}_{3}\right) \delta(\mathrm{ppm}) 8.95(\mathrm{~s}, 1 \mathrm{H}), 7.45(\mathrm{t}, J=$ $1.8 \mathrm{~Hz}, 1 \mathrm{H}), 7.37(\mathrm{t}, J=1.8 \mathrm{~Hz}, 1 \mathrm{H}), 5.12(\mathrm{~s}, 2 \mathrm{H}), 4.38(\mathrm{t}, J=$ $4.7 \mathrm{~Hz}, 2 \mathrm{H}), 3.97(\mathrm{~s}, 3 \mathrm{H}), 3.75(\mathrm{t}, J=4.7 \mathrm{~Hz}, 2 \mathrm{H}), 3.67(\mathrm{t}, J=$ $3.2 \mathrm{~Hz}, 2 \mathrm{H}), 3.60(\mathrm{t}, J=3.2 \mathrm{~Hz}, 2 \mathrm{H}), 3.44(\mathrm{t}, J=6.8 \mathrm{~Hz}, 2 \mathrm{H})$, 1.64 (tq, $J=6.8,7.6 \mathrm{~Hz}, 2 \mathrm{H}), 0.94$ (t, $J=7.6 \mathrm{~Hz}, 3 \mathrm{H})$.

${ }^{13} \mathrm{C} \mathrm{NMR}\left(100 \mathrm{MHz}, \mathrm{CDCl}_{3}\right) \delta(\mathrm{ppm}) 166.23,137.96,123.79$, 123.13, 73.06, 70.54, 69.89, 68.54, 65.66, 49.85, 36.52, 22.75, 10.49 .

IR (thin film on salt plate) $\left(\mathrm{cm}^{-1}\right) 3166,3121,2964,2927,2866$, 1750, 1581, 1574, 1569, 1558, 1495, 1452, 1220, 1181.

MS $m / z, 271.3\left[{\mathrm{M}-B F_{4}}^{-}\right]^{+}$; MS: $m / z, 87.0\left[\mathrm{BF}_{4}^{-}\right]$.

\section{Preparation of 3-methyl-1-(n-butoxycarbonylmethyl) imidazolium $\mathrm{N}(\mathrm{CN})_{2}{ }^{-}$(1e)}

A dry flask was charged with 3-methyl-1-(n-butoxycarbonylmethyl) imidazolium bromide $(3.05 \mathrm{~g}, 11.0 \mathrm{mmol})$ and acetonitrile $(10 \mathrm{~mL})$ under a nitrogen atmosphere. $\mathrm{NaN}(\mathrm{CN})_{2}$ $(1.42 \mathrm{~g}, 16.0 \mathrm{mmol})$ was added in one portion and the suspension was stirred vigorously for 4 days at $20{ }^{\circ} \mathrm{C}$. The fine white precipitate was filtered quickly in air and washed with dry acetonitrile $(2 \times 1 \mathrm{~mL})$. The filtrate and washings were combined, solvent removed by rotary evaporation and then under high vacuum to give a light yellow oil at $20{ }^{\circ} \mathrm{C}$ in $87 \%$ yield $(2.51 \mathrm{~g}$, $9.54 \mathrm{mmol})$.

${ }^{1} \mathrm{H}$ NMR $\left(400 \mathrm{MHz}, \mathrm{CDCl}_{3}\right) \delta(\mathrm{ppm}) 9.82(\mathrm{~s}, 1 \mathrm{H}), 7.56(\mathrm{t}, J=$ $1.8 \mathrm{~Hz}, 1 \mathrm{H}), 7.46(\mathrm{t}, J=1.8 \mathrm{~Hz}, 1 \mathrm{H}), 5.32(\mathrm{~s}, 2 \mathrm{H}), 4.15(\mathrm{t}, J=$ $6.8 \mathrm{~Hz}, 2 \mathrm{H}), 4.02(\mathrm{~s}, 3 \mathrm{H}), 1.61(\mathrm{tt}, J=6.8,7.2 \mathrm{~Hz}, 2 \mathrm{H}), 1.33(\mathrm{tq}$, $J=7.2,7.5 \mathrm{~Hz}, 2 \mathrm{H}), 0.87(\mathrm{t}, J=7.5 \mathrm{~Hz}, 3 \mathrm{H})$.

${ }^{13} \mathrm{C} \mathrm{NMR}\left(100 \mathrm{MHz}, \mathrm{CDCl}_{3}\right) \delta(\mathrm{ppm}) 164.10,136.12,121.89$, 121.18, 64.85, 48.22, 34.87, 28.31, 16.96, 11.67 Note: C's from anion are not visible in ${ }^{13} \mathrm{C} \mathrm{NMR}$.

IR (thin film on salt plate) $\left(\mathrm{cm}^{-1}\right) 2962,2931,2861,2241,2139$, 1750, 1569, 1558, 1539, 1495, 1452, 1217, 1177.

MS $m / z, 197.1\left[\mathrm{M}-\mathrm{N}(\mathrm{CN})_{2}{ }^{-}\right]^{+} ; \mathrm{MS}: m / z, 66.0\left[\mathrm{~N}(\mathrm{CN})_{2}{ }^{-}\right]$. 


\section{Preparation of 3-methyl-1-(2-(n-propoxy)ethoxycarbonylmethyl) imidazolium octylsulfate (5f)}

To a solution of 3-methyl-1-(2-(n-propoxy)ethoxycarbonylmethyl) imidazolium bromide $(3.68 \mathrm{~g}, 12.0 \mathrm{mmol})$ in distilled water $(20 \mathrm{~mL})$ was added in one portion sodium octylsulfate $(2.09 \mathrm{~g}, 9.00 \mathrm{mmol})$. The reaction was stirred at $60^{\circ} \mathrm{C}$ for $2 \mathrm{~h}$ and then water was slowly removed under vacuum. The precipitate was dissolved in DCM $(10 \mathrm{~mL})$ and washed with distilled water $(2 \times 5 \mathrm{~mL})$. The product remaining was dried on the rotary evaporator and then under high vacuum for $8 \mathrm{~h}$ to yield a yellow grease in $85 \%$ yield $(3.33 \mathrm{~g}, 7.62 \mathrm{mmol})$.

${ }^{1} \mathrm{H} \mathrm{NMR}\left(400 \mathrm{MHz}, \mathrm{CDCl}_{3}\right) \delta(\mathrm{ppm}) 9.45(\mathrm{~s}, 1 \mathrm{H}), 7.48(\mathrm{t}, J=$ $1.6 \mathrm{~Hz}, 1 \mathrm{H}), 7.41(\mathrm{t}, J=1.6 \mathrm{~Hz}, 1 \mathrm{H}), 5.25(\mathrm{~s}, 2 \mathrm{H}), 4.36(\mathrm{t}, J=$ $4.7 \mathrm{~Hz}, 2 \mathrm{H}), 4.01(\mathrm{~m}, 5 \mathrm{H}), 3.67(\mathrm{t}, J=4.7 \mathrm{~Hz}, 2 \mathrm{H}), 3.43(\mathrm{t}, J=$ $6.8 \mathrm{~Hz}, 2 \mathrm{H}), 1.63-1.58(\mathrm{~m}, 4 \mathrm{H}), 1.56-1.29(\mathrm{~m}, 10 \mathrm{H}), 0.92-0.86$ $(\mathrm{m}, 6 \mathrm{H})$.

${ }^{13} \mathrm{C} \mathrm{NMR}\left(100 \mathrm{MHz}, \mathrm{CDCl}_{3}\right) \delta(\mathrm{ppm}) 166.45,138.89,123.71$, 123.06, 73.04, 67.92, 67.89, 65.67, 49.91, 36.58, 31.83, 29.50, 29.36, 29.26, 25.87, 22.73, 22.66, 14.13, 10.47 .

IR (thin film on salt plate) $\left(\mathrm{cm}^{-1}\right) 3118,2958,2927,2855,1750$, 1569, 1558, 1539, 1495, 1455, 1217, 1178, 1108.

MS $m / z, 227.1\left[\mathrm{M}-O c t O S O_{3}{ }^{-}\right]^{+}$; MS: $m / z, 209.0\left[\mathrm{OctOSO}_{3}{ }^{-}\right]$.

\section{Acknowledgements}

Enterprise Ireland (NG, SM, BP) and the EPA 2006-PHDET-7 studentship (NG, DC) are gratefully acknowledged for their financial support. We also thank Dr Orla Cahill for her assistance of DF.

\section{References}

1 K. Anderson, P. Goodrich, C. Hardacre and D. Rooney, Green Chem., 2003, 5, 448-453.

2 M. Steffan, M. Lucas, A. Brandner, M. Wollny, N. Oldenburg and P. Claus, Chem. Eng. Technol., 2007, 30, 481-486.

3 P. Wasserscheid and H. Waffenschmidt, J. Mol. Catal. A: Chem., 2000, 164, 61-67.

4 Z. Wang and L. Wang, Appl.Catal. A: Gen., 2004, 262, 101-104.

5 I. Meracz and T. Oh, Tetrahedron Lett., 2003, 44, 6465-6468.

6 J. Liu, G. J. Liu and J. A. Jonsson, Trends Anal. Chem., 2005, 24, 20-27.

7 S. Arenz, A. Babai, K. Binnemans, K. Driesen, R. Giernoth, A. Mudring and P. Nockemann, Chem. Phys. Lett., 2005, 402, 75-79.

8 J. Heredia-Moya and K. Kirk, J. Fluorine Chem., 2007, 128, 674-678.

9 M. J. Earle and K. R. Seddon, Pure Appl. Chem., 2000, 72, 13911398.

10 M. J. Earle, J. Esperanca, M. A. Gilea, J. N. C. Lopes, L. P. N. Rebelo, J. W. Magee, K. R. Seddon and J. A. Widergren, Nature, 2006, 439, 831-834.

11 M. Volland, V. Seitz, Maase, M. Flores, M., R. Papp, K. Massonne, V. Stegmann, K. Halbritter, R. Noe, M. Bartsch, W. Siegel, and Becker, M. Huttenlock, O., PCT Int. Appl. WO03/06225, 2003.

12 B. Weyershausen, K. Hell and U. Hesse, Green Chem., 2005, 7, $283-$ 287.

13 B. Weyershausen and K. Lehmann, Green Chem., 2005, 7, 15-19.

14 K. M. Docherty and C. F. Kulpa Jr, Green Chem., 2005, 7, 185-189.

15 M. Matsumoto, K. Mochiduki and K. Kondo, J. Biosci.Bioeng., 2004, 98, 344-347.

16 J. Pernak, I. Goc and I. Mirska, Green Chem., 2004, 6, 323-329.

17 J. Pernak, K. Sobaszkiewicz and I. Mirska, Green Chem., 2002, 5, 52-56.

18 C. Pretti, C. Chiappe, D. Pieraccini, M. Gregori, F. Abramo, G. Monni and L. Intorre, Green Chem., 2005, 8, 238-240.
19 A. Latala, P. Stepnowski, M. Nedzi and W. Mrozik, Aquat. Tox., 2005, 73, 91-98.

20 C. Cho, T. P. Pham, Y. Jeon and Y. Yun, Green Chem., 2008, 10, $67-72$.

21 G. Lamberti and K. Kulacki, Green Chem., 2008, 10, 104-110.

22 B. Jastorff, K. Molter, P. Behrend, U. Bottin-Weber, J. Filser, A. Heimers, B. Ondruschka, J. Ranke, M. Schaefer, H. Schroder, A. Stark, P. Stepnowski, F. Stock, R. Stormann, S. Stolte, U. WelzBiermann, S. Ziegert and J. Thoming, Green Chem., 2005, 7, 362 372.

23 P. Balczewski, B. Bachowska, T. Bialas, R. Biczak, W. Wieczorek and A. Balinska, J. Agric. Food Chem., 2007, 55, 1881-1892.

24 R. P. Swatloski, J. D. Holbrey, S. B. Memon, G. A. Caldwell, K. A. Caldwell and R. D. Rogers, Chem. Commun., 2004, 668-669.

25 R. J. Bernot, E. E. Kennedy and G. A. Lamberti, Environ. Toxicol. Chem., 2005, 24, 1759-1765.

26 J. Ranke, A. Muller, U. Bottin-Weber, F. Stock, S. Stolte, J. Arning, R. Stormann and B. Jastorff, Ecotoxicol. Environ. Safety, 2007, 67, 430-438.

27 S. Stolte, J. Arnig, U. Bottin-Weber, A. Muller, W. Pitner, U. WelzBiermann, B. Jastorff and J. Ranke, Green Chem., 2007, 9, 760-767.

28 A. García-Lorenzo, E. Tozo, J. Tojo, M. Teijeira, F. J. RodríguezBerrocal, M. P. González and V. S. Martínez-Zorzano, Green Chem., 2008, 10, 508-516.

29 F. Stock, J. Hoffmann, J. Ranke, R. Stormann, B. Ondruschka and B. Jastorff, Green Chem., 2004, 6, 286-290.

30 D. J. Couling, R. J. Bernot, K. M. Docherty, J. K. Dixon and E. J. Maginn, Green Chem., 2006, 8, 82-90.

31 N. Gathergood and P. J. Scammells, Aust. J. Chem., 2002, 55, $557-$ 560.

32 N. Gathergood, M. T. Garcia and P. J. Scammells, Green Chem., 2004, 6, 166-175.

33 M. T. Garcia, N. Gathergood and P. J. Scammells, Green Chem., 2004, 7, 9-14.

34 N. Gathergood, P. J. Scammells and M. T. Garcia, Green Chem., $2006,8,156-160$.

35 K. Docherty, J. Dixon and C. Kulpa, Biodegradation, 2007, 18, 481 493.

36 A. Romero, A. Santos, J. Tojo and A. Rodriguez, J. Hazard. Mater., 2008, 151, 268-273.

37 S. Stolte, S. Abdulkarim, J. Arning, A. K. Blomeyer-Nienstedt, U. Bottin-Weber, M. Matzke, J. Ranke, B. Jastorff and J. Thoming, Green Chem., 2007, 10, 214-224.

38 A. Wells and V. Coombe, Org. Process Res. Dev., 2006, 10, 794-798.

39 J. R. Harjani, R. D. Singer, M. T. Garcia and P. J. Scammells, Green Chem., 2008, 10, 436-438.

40 P. Nockemann, B. Thijs, K. Driesen, C. Janssen, K. Van Hecke, L. Van Meervelt, S. Kossmann, B. Kirchener and K. Binnemans, J. Phys. Chem. B, 2007, 111, 5254-5263.

41 J. R. Harjani, R. Singer, M. T. Garcia and P. J. Scammells, Green Chem., 2009, 11, 83-90.

42 S. T. Elder, A. Preuss, K.-U. Schoning and K. Muhlbauer, Pub. No.: US 2008/0070966 A1.

43 P. Wasserscheid, R. van Hal and A. Bosmann, Green Chem., 2002, 4, 400-404.

44 S. Morrissey, I. Beadham and N. Gathergood, Green Chem., 2009, 11, DOI: $10.1039 / \mathrm{b} 815566 f$.

45 D. Demberelnyamba, K.-S. Kim, S. Choi, S.-Y. Park, H. Lee, C.-J. Kim and I.-D. Yoo, Bioorg. Med. Chem., 2004, 12, 853-857.

46 N. Bodor, R. Woods, C. Raper, P. Kearney and J. J. Kaminski, J. Med. Chem., 1980, 23, 474-480.

47 N. Bodor, J. J. Kaminski and S. Selk, J. Med. Chem., 1980, 23, 469 474.

48 N. Bodor and J. J. Kaminski, J. Med. Chem., 1980, 23, 566-569.

49 N. Bodor, Pat., US 39897111, 1976.

50 N. Bodor, Pat., US 4160099, 1979.

51 ISO 14593: Water quality, Evaluation of ultimate aerobic biodegradability of organic compounds in aqueous medium. Method by analysis of inorganic carbon in sealed vessels $\mathrm{CO}_{2}$, headspace test, 1999.

52 D. Amsterdam, 1991. Susceptibility testing of antimicrobials in liquid media, 72-78. In Antibiotics in Laboratory Medicine, 3rd edition. Ed. V. Lorian, Williams and Wilkins, Baltimore. 